\title{
Effect of Pruning height on Different Varieties of Mulberry in Eastern Dry Zone of Karnataka, India
}

\author{
R. N. Bhaskar*, H. G. Anusha and K. V. Anitharani \\ Department of Sericulture, UAS GKVK, Bengaluru-560065 (Karnataka), India \\ *Corresponding author
}

A B S T R A C T

Key w o r d s
Mulberry
genotypes, Middle
pruning, mulberry
growth parameters

Mulberry (Morus indica) is considered as sole food plant of silkworm Bombyx mori L. The nutritive value of mulberry leaf is most important factor influenced by environment and cultivation practices. Pruning is one of the cultural activity includes methodical removal of certain branches with an objective of giving proper size and shape to increase the leaf quality and yield. Therefore pruning of mulberry to the height of $60-90 \mathrm{~cm}$ above the ground level is a very common practice adopted under rainfed condition. The study revealed that, maximum number of shoots $(12.44,16.40$, and 19.57$)$ and more shoot length $(29.85,76.87,109.32 \mathrm{~cm})$ was observed in $\operatorname{Tr}-10$ variety on $15,30^{\text {th }}$ and 45 days after pruning. Further, the data on maximum number of leaves $(9.20,15.89,21.99)$ was recorded in S-34 variety whereas the internodal distance $(5.67,7.698 .08 \mathrm{~cm})$ and leaf area (58.32, 175.12 and $224.04 \mathrm{~cm}^{2}$ ) was recorded in $\mathrm{Tr}-10$. However, the next increased leaf area was recorded after $30\left(123.72 \mathrm{~cm}^{2}\right)$ and $45\left(163.37 \mathrm{~cm}^{2}\right)$ days after pruning in $\mathrm{S}-34$ followed by MR-2. However, the maximum leaf moisture content of 78.42 per cent was recorded for S-36 followed by S-54 (76.95 \%) and S-34 (76.31\%).

\section{Introduction}

Mulberry leaf is the sole food material and its nutrition is necessary for growth regulating factors in silkworm, Bombyx mori L. Silkworm derives proteins directly from the mulberry leaves for producing nearly 70 per cent of silk. Unpruned mulberry plant was found to produce less quantity of leaves with poor quality. Periodic pruning is important to maintain vigorous young shoots and foliage with proper nutrients. In irrigated condition, where intensive cultivation is carried out, it is necessary to prune the plants to maintain their peak production. Whereas in rainfed condition mulberry is pruned to the height of $60-90 \mathrm{~cm}$ as middle pruning above the ground level to sustain moisture in the shoot and enhanced vegetative growth in mulberry which in turn enhance the leaf yield and quality (Rangaswami et al., 1976).

Nutritive value of mulberry leaf is a most important factor which is decided by environment and technology adoption for better silkworm cocoon crop. 
Among various factors influencing silkworm growth, leaf quality plays a major role. The leaf quality differs among mulberry varieties which influenced by mulberry variety cultivation practices (pruning and harvesting), age and position of the leaf was determined based on moisture content, moisture retention capacity.

Now-a-days, mostly the farmers take up bottom pruning at frequent intervals with shoot harvest i.e., 5-6 times per year for continuous silkworm rearing. Consequent to severe pruning, the crop fails to produce more biomass and requires large quantities of nutrients for regeneration (Thangamalar et al., 2018).

This practice has directly or indirectly affected the soil fertility and plant growth rate. Therefore maintaining single shoot in each bush found very effective in increasing the number of shoots per plant, Length of the shoots, Number of leaves per shoots, Internodal distance $(\mathrm{cm})$, leaf area $\left(\mathrm{cm}^{2}\right)$ and other quantitative parameters of leave viz., moisture content, moisture retention capacity after different hours after harvesting varied with changes in the pruning heights e.g. progressive and significant decrease in leaf yield with the increase in number of shoot pruning at the ground level. Keeping in view, the study of importance of middle pruning on growth and nutritional value of different mulberry leaves was carried out in Eastern dry zone of Karnataka.

\section{Materials and Methods}

The experiment was carried out in the Department of Sericulture, Gandhi Krishi Vignana Kendra, Bangalore is located at $77^{\circ} 35^{\prime}$ E longitude and $12^{\circ} 58^{\prime} \mathrm{N}$ latitude at an altitude of $930 \mathrm{~m}$ above mean sea level during Kharif season (July - September 2019).
The varieties selected from 20 year old mulberry garden which was maintained as a single stump. The mulberry varieties viz., Mysore local, S-54, S-36, MR-2, S-34 and DD were pruned at $45-60 \mathrm{~cm}$ above the ground level, from each plant single shoot is retained and maintained as stump. The observations were made in each mulberry variety (30 plants/ variety and 4 replication)at 15,30 and 45 days after pruning.

The growth parameters of mulberry viz., Number of shoots per plant, Length of the shoots $(\mathrm{cm})$, Number of leaves per shoots, Internodal distance $(\mathrm{cm})$, leaf area $\left(\mathrm{cm}^{2}\right)$ and leaf quality parameters viz., moisture percent (\%) and moisture retention capacity (6hr, 12 $\mathrm{hr}$ and $24 \mathrm{hr}$ )were recorded from each plant. The statistical analysis was carried out by using Randomized Complete Block Design.

\section{Number of shoots per plant}

The number of shoots per plant (stump) from five randomly selected plants in each replication was counted .

\section{Longest shoot height $(\mathrm{cm})$}

The longest shoot height was measured from the middle pruned plants to the tip, at 15, 30 and 45 days after pruning.

\section{Number of leaves per shoot}

The numbers of leaves were counted from shoots of the labeled plants in each plot at 15 30 and 45 days after pruning.

\section{Single leaf area}

Single Leaf area (LA) of five randomly selected fully opened leaf was determined by multiplying length $\mathrm{x}$ breadth with a constant factor 0.6898 . 


\section{Moisture percentage (\%)}

The Moisture percentage of the leaf was estimated at 15, 30 and 45 days after pruning following A.O.A.C. (1970).

Leaf moisture $(\%)=\frac{\text { Fresh weight of leaf }- \text { dry weight of leaf }}{\text { Fresh weight of leaf }} \times 100$

\section{Results and Discussion}

The experimental data revealed that, there was a significant difference between the treatments with respect to all the growth parameters of mulberry. The maximum number of shoots was noticed in $\operatorname{Tr}-10$ (12.44, 16.40 and 19.57) which resulted in significant difference with all other mulberry varieties. In addition, S-54 $(6.43,7.75 \& 8.55 \mathrm{~cm})$ and S$36(6.24, \quad 7.29 \quad \& \quad 8.51 \mathrm{~cm})$ and MR-2 $(6.80,7.89 \& 9.00 \mathrm{~cm})$ were found on par with each other and minimum was noticed in both DD (3.27 cm ) and Mysore local ( 3.80 $\& 4.73 \mathrm{~cm}$ ) varieties at 15,30 and 45 days after middle pruning.
The maximum and minimum shoot length was observed in Tr-10 and DD variety, where as significant difference was noticed in between Mysore Local (19.99, 57.77 \& 91.66) and TR-10 (29.85, $76.87 \& 109.32)$, Tr-10 and S-54(15.47, $44.10 \& 86.78)$, MR$2(22.24,45.36 \& 86.33)$ and $\operatorname{DD}(8.31,27.11$ \& 63) (Table 1). These results are in confirmative with findings of (Deeraj Kumar et al., 2016) they recorded, the maximum number of shoots per plant (20,) longest shoot length $(101.60 \mathrm{~cm})$ in $\operatorname{Tr}-10$ variety. Further, (Balakrishna et al., 1999) also observed same minimum total shoot length in Mysore local variety $(750.66 \mathrm{~cm})$. The higher number of leaves per shoot was noticed in S-34(9.20, 15.89, and 21.99) and minimum was in DD (5.27, 10 \&14.33). Further, Tr-10(5.67) variety was recorded higher internodal distance followed by Mysore Local (4.83), MR-2 (4.57), S-54(3.66), S-36(3.51), and DD (2.60) after 15 days after pruning but the trend was not same on 30 and 45 days after middle pruning, whereas minimum was found in $\mathrm{DD}(3.80)$ and $\mathrm{S}-36(4.88)($ Table 2).

Table.1 Effect of middle pruning on growth parameters of different mulberry varieties under eastern dry zone of Karnataka (Number of shoots and Length of the shoots)

\begin{tabular}{|c|c|c|c|c|c|c|c|c|}
\hline \multirow[t]{2}{*}{ Treatment } & \multicolumn{3}{|c|}{ Number of shoots (No.) } & \multirow[b]{2}{*}{ Mean } & \multicolumn{3}{|c|}{ Length of the shoots (Cm) } & \multirow[b]{2}{*}{ Mean } \\
\hline & 15DAP & 30 DAP & $45 \mathrm{DAP}$ & & 15 DAP & 30 DAP & 45 DAP & \\
\hline Mysore local & 3.53 & 3.80 & 4.73 & 4.02 & 19.99 & $\mathbf{5 7 . 7 7}$ & 91.66 & 56.47 \\
\hline Tr-10 & 12.44 & 16.40 & 19.57 & 16.14 & 29.85 & 76.87 & 109.32 & 72.01 \\
\hline S-54 & 6.43 & 7.75 & 8.55 & 7.58 & 15.47 & 44.10 & 86.78 & 48.78 \\
\hline S-36 & 6.24 & 7.29 & 8.51 & 7.35 & 24.51 & 43.11 & 69.33 & 45.65 \\
\hline MR-2 & 6.80 & 7.89 & 9.00 & 7.90 & 23.67 & 52.05 & 78.22 & 51.31 \\
\hline S-34 & 4.67 & 5.03 & 6.15 & 5.28 & 22.24 & 45.36 & 86.33 & 51.31 \\
\hline DD & 3.27 & 5.44 & 7.07 & 5.26 & 8.31 & 27.11 & 63.00 & 32.81 \\
\hline \multicolumn{9}{|l|}{ F- test } \\
\hline SEm \pm & 0.63 & 0.53 & 0.43 & & 2.34 & 3.30 & 5.01 & \\
\hline C D at $1 \%$ & 1.94 & 1.65 & 1.35 & & 7.23 & 10.17 & 15.45 & \\
\hline
\end{tabular}


Table.2 Effect of middle pruning on growth parameters of different mulberry varieties under eastern dry zone of Karnataka (Number of leaves / shoot, Internodal distance and Single Leaf area)

\begin{tabular}{|c|c|c|c|c|c|c|c|c|c|c|c|c|}
\hline \multirow[t]{2}{*}{ Treatment } & \multicolumn{3}{|c|}{ Number of leaves / shoot (No.) } & \multirow[t]{2}{*}{ Mean } & \multicolumn{3}{|c|}{ Internodal distance (Cm) } & \multirow[t]{2}{*}{ Mean } & \multicolumn{3}{|c|}{ Single Leaf area $(\mathrm{Cm} 2)$} & \multirow[t]{2}{*}{ Mean } \\
\hline & 15DAP & 30 DAP & 45 DAP & & 15 DAP & 30 DAP & 45 DAP & & 15 DAP & 30 DAP & 45 DAP & \\
\hline Mysore local & 6.53 & 13.67 & 18.78 & 12.99 & 4.83 & 6.50 & 7.47 & 6.27 & 40.05 & 121.24 & 139.70 & 100.33 \\
\hline Tr-10 & 7.40 & 14.36 & 16.33 & 12.70 & 5.67 & 7.69 & 8.08 & 7.15 & 58.32 & 175.12 & 224.04 & 152.49 \\
\hline S-54 & 7.33 & 13.22 & 20.33 & 13.63 & 3.66 & 5.50 & 5.74 & 4.97 & 46.53 & 93.52 & 125.87 & 88.64 \\
\hline S-36 & 8.27 & 14.00 & 18.22 & 13.50 & 3.51 & 4.24 & 4.66 & 4.14 & 57.69 & 84.64 & 131.90 & 91.41 \\
\hline MR-2 & 8.13 & 15.22 & 18.52 & 13.96 & 4.57 & 5.10 & 5.15 & 4.94 & 58.51 & 122.00 & 163.37 & 114.63 \\
\hline S-34 & 9.20 & 15.89 & 21.99 & 15.69 & 3.39 & 4.34 & 4.80 & 4.18 & 74.98 & 123.72 & 156.43 & 118.38 \\
\hline DD & 5.27 & 10.00 & 14.33 & 9.87 & 2.60 & 3.80 & 4.88 & 3.76 & 25.28 & 92.32 & 114.60 & 77.40 \\
\hline \multicolumn{13}{|l|}{ F- test } \\
\hline SEm \pm & 0.61 & 1.08 & 1.22 & & 0.35 & 0.30 & 0.26 & & 5.53 & 11.19 & 10.51 & \\
\hline C D at $1 \%$ & 1.88 & 3.34 & 3.76 & & 1.10 & 1.10 & 0.82 & & 17.04 & 34.49 & 32.40 & \\
\hline
\end{tabular}

Table.3 Effect of middle pruning on quality parameters of different mulberry varieties under eastern dry zone of Karnataka

(Moisture content and Moisture retention capacity)

\begin{tabular}{|c|c|c|c|c|c|c|c|c|c|c|}
\hline \multirow[t]{3}{*}{ Treatment } & \multicolumn{4}{|c|}{15 DAP } & \multirow{3}{*}{ Mean } & \multicolumn{4}{|c|}{30 DAP } & \multirow{3}{*}{ Mean } \\
\hline & \multirow{2}{*}{$\begin{array}{l}\text { Moisture } \\
\text { Content (\%) }\end{array}$} & \multicolumn{3}{|c|}{ Moisture retention capacity } & & \multirow{2}{*}{$\begin{array}{l}\text { Moisture } \\
\text { Content (\%) }\end{array}$} & \multicolumn{3}{|c|}{ Moisture retention capacity } & \\
\hline & & $6 \mathrm{hr}$ & $12 \mathrm{hr}$ & $24 \mathrm{hr}$ & & & $6 \mathrm{hr}$ & $12 \mathrm{hr}$ & $24 \mathrm{hr}$ & \\
\hline Mysore local & 71.49 & 65.17 & 61.11 & 60.81 & 62.36 & 71.29 & 65.06 & 61.05 & 60.45 & 62.19 \\
\hline Tr-10 & 72.69 & 79.18 & 73.16 & 71.27 & 74.54 & 72.35 & 79.11 & 73.44 & 70.46 & 74.34 \\
\hline S-54 & 76.95 & 76.18 & 71.85 & 68.55 & 72.19 & 76.52 & 76.23 & 71.56 & 68.39 & 72.06 \\
\hline S-36 & 78.42 & 84.87 & 80.62 & 77.58 & 81.02 & 79.76 & 83.73 & 81.53 & 77.20 & 80.82 \\
\hline MR-2 & 73.76 & 76.60 & 72.22 & 69.34 & 72.72 & 73.32 & 76.32 & 73.84 & 69.36 & 73.17 \\
\hline S-34 & 76.31 & 83.15 & 77.10 & 72.75 & 77.67 & 76.16 & 83.07 & 78.26 & 72.56 & 77.96 \\
\hline DD & 72.29 & 67.76 & 61.89 & 60.99 & 63.55 & 72.23 & 67.34 & 62.00 & 60.81 & 63.38 \\
\hline F- test & & & & & & NS & & & & \\
\hline SEm \pm & 0.85 & 1.90 & 1.44 & 0.73 & & & 2.07 & 2.62 & 3.10 & \\
\hline C D at $1 \%$ & 2.61 & 5.84 & 4.45 & 2.26 & & & 6.39 & 8.09 & 9.55 & \\
\hline
\end{tabular}


The same trend was observed by (Balakrishna et al., 1999) according to them Nodes/ meter was recorded in decreasing order from MR-2 (26.66), S-36 (31.33) and Mysore local (32) respectively. Further, the maximum Internodal distance $(6.90 \mathrm{~cm}$.) in $\mathrm{Tr}-10$ variety as it is reflected in the present experiment (Deeraj Kumar et al., 2016). The single leaf area was found more in $\operatorname{Tr}-10$ (58.32) followed byMR-2 (58.21) and less was noticed in $\mathrm{DD}\left(25.28 \mathrm{~cm}^{2}\right)$ after 15 DAP even trend was same even in after 30 and 45 days (maximum in $\operatorname{Tr}-10$ - 175.12\&224.04 and minimum in DD- $92.32 \& 114.60$ ) (Table 3).

The significant difference was noticed in moisture content (\%) of leaves only after 15 DAP whereas the observation after 30 days found non-significant among mulberry varieties. However, maximum of 78.42 and minimum of 71.49 percent leaf moisture was recorded in S-36 and Mysore local variety respectively. Further, the moisture retention capacity after $6 \mathrm{hr}$ (84.87) $12 \mathrm{hr}$ (80.62) and $24 \mathrm{hr}$ (77.58) was found more in S-36 variety and less in Mysore Local (65.17, 61.11 \& 60.81 ) after 15 DAP similar trend was noticed even in 30 DAP in all the mulberry varieties (Table 3).

These results are confirmative with findings of (Shree et al., 2007) the moisture content $(72.20 \%)$ and moisture retention capacity (72.83 after $4 \mathrm{hr}$ ) was found in S-36 mulberry variety. Kaushal Kumar et al., (2018) also observed, the same trend with respect to leaf moisture and moisture retention capacity after $6 \mathrm{hr}$ of preservation. According to (Mir et al., 2012) the moisture content $(71.95 \%)$ and moisture retention ( 85.48 and $75.84 \%$ ) after 6 and $12 \mathrm{hr}$ was found in TR-10 mulberry variety as observed in the present study. It is attributed that, the upper cuticle thickness $(5.14 \mu \mathrm{m})$ lower cuticle thickness $(2.13 \mu \mathrm{m})$ and upper epidermal thickness(19.60 $\mu \mathrm{m})$, lower epidermal thickness $(7.80 \mu \mathrm{m})$ and stomata frequency609.21 mm considered as strong leaf parameters to retain more moisture in the leaf lamina in $\operatorname{Tr}-10$ variety.

According to (Rajath Mohan et al., 2003)the moisture percentage in TR-10 (75.28 \%)was significantly more compared to S13(74.23).However, higher moisture content in S-36 was found more is due to thickness of leaf lamina(121.68), palasade mesophyll percentage (58.93) and number of stomata / $\mathrm{mm}$ is 830 compared to other mulberry varieties (Jajala S Kumar et al., 2003).

\section{References}

A.O.A.C., 1970.Official Methods of Analysis. (Ed. Daniel banes) published by A.O.A.C. Washington, D.C. Bangalore. P. 105.

Balakrishna, R., Jalaja S. Kumar, Kavitha, V., and Sarkar, A. 1999. Screening of mulberry (Morus sp.) genotypes for tolerance to coconut shade, Moriculture in tropics. Proceedings of National Seminar on Tropical Sericulture, Pp:6870.

Dheeraj Kumar, Sapna Rajput, AvinderKour, Arun Kumar, Abdul Aziz Danish, ShahidHamadani, Harjeet Singh, Rajat Mohan and Chhattar Pal, 2016. Evaluation and characterization of improved mulberry genotypes. Journal of Global Biosciences.5(4):3884-3891.

Jalaja S. Kumar, Babu, A. M. and Sarkar, A., 2003. Anatomical adaptations of mulberry leaf under induced moisture stress. Advances in Tropical Sericulture, Proceedings of the National Conference on Tropical Sericulture for Global Competitiveness. Pp:9-11.

Kushal Kumar, Mukesh Mohan, NalniTiwari and SanjeevKumar, 2018, Production potential and leaf quality evaluation of selected mulberry (Morus alba) clones. 
J.Pharmacogn. Phytochem.,7(2):482486.

Mir, M.R., AminaKhan, Anil Dhar, Mir, A. Q. and Wani, T. A., 2012. Leaf moisture status of some mulberry genotypes as influenced by their foliar anatomy. Indian J. Seric., 51(1)1-6.

Rajat Mohan, Singh, B. D., Srivastava, V. B., Singh, S., Juyal, A.C., Ramakant and Singh, P.K. 2003.Screening of mulberry genotypes suitable for ecozones of Uttar Pradesh and Uttaranchal. Proceedings of the National Conference on Tropical Sericulture for global Competitivenes. Pp:12-14.

Rangaswami.G., Narasimhanna, M. N.,
Kasiviswanathan, K. andSastry, C. R. 1976.Mulberry Cultivation.FAO Sericulture manual-1.Pp:1-150

Shree, M. P.,Vamseedhar, P. and Nagaveni, V. 2007. Changes in the moisture content and stomatal variation in turka affected S-36 mulberry variety. Bull. Ind. Acad. Seri.11(1):5-10.

Thangamalar, A., Ramamoorthy, K., Prabhu, S. and Priyadarshini, P. 2018. Influence of different pruning techniques and integrated nutrient management ongrowth, leaf yield of mulberry and its impact on silkworm (BombyxmoriL.) Bioassay. Int. J. Curr. Micro.biol.App. Sci. 7(2): 2963-2971.

\section{How to cite this article:}

Bhaskar. R. N., H. G. Anusha and Anitharani. K. V. 2020. Effect of Pruning height on Different Varieties of Mulberry in Eastern Dry Zone of Karnataka, India. Int.J.Curr.Microbiol.App.Sci. 9(06): 2839-2844. doi: https://doi.org/10.20546/ijcmas.2020.906.343 